\title{
PEMANFAATAN LIMBAH CAIR PEMINDANGAN IKAN
}

\section{THE UTILIZATION OF BOILED FISH WASTE WATER}

\author{
Arieyanti Dwi Astuti \\ Kantor Penelitian dan Pengembangan Kabupaten Pati \\ E-mail: ariey_antik@yahoo.com
}

Naskah Masuk:18 September 2014 Naskah Revisi: 2 Oktober $2014 \quad$ Naskah Diterima: 16 )otober 2014

\begin{abstract}
The enhancement number of boiled fish production will always followed by the increase of waste volume, especially wastewater that in the process will be dumped into the environment. Whereas, if it used with technology development varieties, boiled fish wastewater potentially produce new products. This is because the content of the materials in boiled fish wastewater that useful, such as proteins, fats, salts, and others. That's required an effort that is able to utilizing wastewater boiled fish, as well as to create new products from utilization results of the wastewater. This review aims to provide an overview about the use of wastewater boiled fish that has not been widely known and applied to the community, especially in coastal area of Pati Regency which related to the boiled fish industry. Boiled fish wastewater can be utilized as raw material for the manufacture of fish paste, animal feed and organic liquid fertilizer.
\end{abstract}

Keywords: boiled fish wastewater, animal feed, utilization, fish paste, organic liquid fertilizer

\begin{abstract}
ABSTRAK
Peningkatan jumlah produksi pemindangan ikan akan selalu diikuti dengan peningkatan volume limbah, terutama limbah cair yang dalam prosesnya akan dibuang begitu saja ke lingkungan. Padahal jika dimanfaatkan dengan berbagai pengembangan teknologi, limbah cair pemindangan ikan ini berpotensi menghasilkan produk-produk baru. Hal ini dikarenakan adanya kandungan bahan-bahan yang terdapat pada limbah cair pemindangan ikan yang bermanfaat, seperti protein, lemak, garam, dan lain-lain. Untuk itulah diperlukan suatu upaya yang mampu memanfaatkan limbah cair pemindangan ikan, sekaligus menciptakan produk-produk baru dari hasil pemanfaatan limbah cair tersebut. Review ini bertujuan untuk memberikan gambaran mengenai pemanfaatan limbah cair pemindangan ikan yang belum banyak diketahui dan diterapkan pada masyarakat, terutama masyarakat di kawasan pesisir di Kabupaten Pati yang banyak berhubungan dengan industri pemindangan ikan. Limbah cair pemindangan ikan dapat dimanfaatkan menjadi bahan baku pembuatan petis ikan, pakan ternak dan pupuk cair organik.
\end{abstract}

Kata kunci: limbah cair pemindangan ikan, pakan ternak, pemanfaatan, petis ikan, pupuk organik cair 
PENDAHULUAN

Potensi perikanan di Indonesia sangat besar mencapai 6,7 juta ton per tahun yang belum dimanfaatkan secara maksimal karena baru 59\% dimanfaatkan dari total kekayaan perikanan yang ada. Pemanfaatan total produksi perikanan di Indonesia sebagian besar dikonsumsi dalam bentuk ikan segar sebesar 57,05\%, bentuk olahan tradisional sebesar $30,19 \%$, dan bentuk olahan modern sebesar $10,90 \%$ serta olahan lainnya sebesar 1,86\% (Rahmania dalam Oktavia $\mathrm{dkk}, 2012$ ). Pemanfaatan dalam bentuk olahan ikan tradisional antara lain berupa ikan asin, ikan pindang dan produk fermentasi seperti terasi, petis dan sebagainya. Salah satu produk olahan ikan yang banyak dihasilkan di Kabupaten Pati adalah ikan pindang. Ikan pindang banyak dihasilkan di Kabupaten Pati selain Kota Pekalongan dan Kabupaten Rembang di wilayah Jawa Tengah. Bahan baku yang digunakan untuk industri ikan pindang antara lain: ikan layang, selar, kembung, tongkol, bandeng dan lain-lain. Unit pengolahan pemindangan ikan mencapai 100 unit atau sekitar 18,52\% dari total unit pengolahan ikan di Kabupaten Pati.

Hasil produksi ikan pindang di Kabupaten Pati mencapai 43.000 ton pada tahun 2011, dimana jumlah ini mengalami peningkatan signifikan dari tahun 2010 yang hanya menghasilkan produksi ikan pindang sebesar 27.815 ton (Dislautkan Kab. Pati, 2013). Dengan konsumsi ikan pindang yang terus mengalami peningkatan, pemerintah daerah masih belum bisa memberikan perhatian secara maksimal terhadap para pengusaha ikan pindang. Sampai saat ini, pengolahan ikan pindang masih menggunakan pengolahan tradisional dimana jika dilihat dari segi higienis, kesegaran bahan baku, pengemasan dan pemasaran banyak yang masih dilakukan secara manual. Selain itu, ketiadaan instalasi atau unit pengelolaan limbah baik limbah padat maupun limbah cair.

Proses pengolahan ikan pindang akan memberikan hasil samping berupa limbah, terutama limbah cair yang dihasilkan dari proses pencucian dan perebusan ikan dalam jumlah yang tidak sedikit. Umumnya pengusaha ikan pindang tradisional tidak melakukan penanganan limbah sebelum membuang air limbah ke badan air penerima (sungai), yang pada akhirnya mengakibatkan pencemaran air dan menimbulkan bau busuk.

Limbah cair industri pemindangan ikan berpotensi mencemari lingkungan karena mengandung banyak bahan organik (Dislautkan Kab. Pati, 2013). Seperti yang diungkapkan Gonzales dalam Oktavia dkk (2012), bahwa air limbah hasil buangan industri pengolahan hasil laut mengandung berbagai macam bahan organik seperti sisa daging, isi perut, protein, lemak dan karbohidrat yang akan berpengaruh terhadap karakteristik air limbah tersebut. Sejauh ini limbah cair dari proses pemindangan ikan belum dimanfaatkan secara optimal. Padahal jika dimanfaatkan dengan berbagai pengembangan teknologi, limbah cair pemindangan ikan berpotensi menghasilkan produk-produk baru. Hal ini dikarenakan adanya kandungan bahan-bahan yang terdapat pada limbah cair pemindangan ikan yang bermanfaat, seperti protein, lemak, garam, dan lainlain.

Untuk itulah diperlukan suatu upaya yang mampu memanfaatkan limbah cair pemindangan ikan sekaligus 
menciptakan produk-produk baru hasil pemanfaatan limbah cair tersebut. Diharapkan dengan pemanfaatan limbah cair pemindangan ikan ini akan mampu meningkatkan kesejahteraan masyarakat dengan adanya kesempatan kerja baru, menjaga bahkan memperbaiki kualitas lingkungan secara berkelanjutan. Review ini bertujuan untuk memberikan gambaran mengenai pemanfaatan limbah cair pemindangan ikan yang belum banyak diketahui dan diterapkan pada masyarakat, terutama masyarakat di kawasan pesisir di Kabupaten Pati yang banyak berhubungan dengan industri pemindangan ikan.

\section{LIMBAH CAIR PEMINDANGAN IKAN}

Salah satu sumber limbah cair pada pemindangan ikan berasal dari proses perebusan ikan dengan garam dan hasil meniriskan ikan. Limbah cair pemindangan ikan banyak mengandung protein dan lemak sehingga berpotensi meningkatkan kandungan $\mathrm{BOD}_{5}$ dan TSS (Murniati, 2007). Hal yang sama juga diungkapkan dalam penelitian Suyasa dalam Oktavia dkk (2012), yang menyatakan bahwa bahan organik terlarut dan tersuspensi dapat menjadi sangat tinggi pada air limbah proses perikanan sehingga akan meningkatkan $\mathrm{BOD}_{5}$ dan COD. Timbulnya bau busuk disebabkan oleh dekomposisi lanjut protein dan juga dekomposisi bahan organik. Selain itu, kandungan minyak lemak di permukaan air akan menghambat proses biologis dalam air sehingga dapat menghasilkan gas yang berbau.

Komponen yang terkandung dalam limbah cair pemindangan ikan disajikan pada Tabel 1.

Tabel 1.

Hasil Pengujian Limbah Cair Pemindangan Ikan

\begin{tabular}{lccc}
\hline \multirow{2}{*}{ Parameter } & Satuan & \multicolumn{2}{c}{ Industri Pemindangan Ikan } \\
\cline { 3 - 4 } & & A & B \\
\hline $\mathrm{pH}$ & $\mathrm{mg} / \mathrm{l}$ & 2210,85 & 5,2 \\
$\mathrm{TSS}$ & $\mathrm{mg} / \mathrm{l}$ & 0,32 & $0,1870,652$ \\
Sulfida & $\mathrm{mg} / \mathrm{l}$ & 16,128 & 9,303 \\
Amonia & $\mathrm{mg} / \mathrm{l}$ & 639,235 & 460,12 \\
BOD $_{5}$ & $\mathrm{mg} / \mathrm{l}$ & 2037,28 & 1457,138 \\
$\mathrm{COD}$ & $\mathrm{mg} / 1$ & 13,44 & 6,275 \\
Minyak Lemak & $\mathrm{mg} / \mathrm{l}$ & 1,685 & 0,42 \\
Protein & $\%$ & 0,08 & 0,03 \\
Kadar Abu & $\%$ & 3,52 & 1,35 \\
Kadar Garam & $\%$ & 93,495 & 95,088 \\
Kadar Air & & &
\end{tabular}

Sumber: Hasil Pengujian, 2014.

Keterangan: industri A, industri dengan jumlah produksi 6-7 ton/hari industri $\mathrm{B}$, industri dengan jumlah produksi 2-3 ton/hari 
Pada Tabel 1 disebutkan, bahwa terdapat 2 industri pemindangan ikan yang diuji limbah cairnya yaitu industri A untuk industri yang memproduksi 6-7 ton ikan pindang per hari dan industri B yang memproduki ikan pindang 2-3 ton ikan per hari. Dari tabel $1 \mathrm{di}$ atas, terlihat bahwa kandungan parameter limbah cair pada industri A lebih tinggi dari industri B. Hal ini dimungkinkan karena jumlah ikan yang diproduksi pada industri A lebih tinggi dari industri B. Semakin banyak jumlah ikan yang diproduksi maka semakin tinggi kandungan bahan organik. Tingginya bahan organik menyebabkan kandungan beberapa parameter pada industri A lebih tinggi dari industri B.

\section{PETIS IKAN}

Limbah perikanan khususnya limbah cair, biasanya langsung dibuang ke lingkungan dan dapat menyebabkan pencemaran serta menimbukan bau yang mengganggu estetika lingkungan (Wijatmoko, 2004). Dengan kandungan yang dimiliki, limbah cair sisa pemindangan ikan masih mengandung sejumlah zat gizi dan komponen lain yang terlarut selama perebusan ikan (Tabel 1). Oleh karena itu, limbah tersebut dapat dimanfaatkan kembali untuk digunakan sebagai bahan baku pembuatan petis ikan seperti pada penelitian yang dilakukan Danitasari (2010).

Petis ikan yang merupakan hasil samping dari proses pemindangan ikan dengan air garam mengakibatkan petis ikan memiliki daya awet yang cukup tinggi, dimana garam dengan konsentrasi cukup tinggi berfungsi sebagai pengawet atau penghambat pertumbuhan mikroba pembusuk serta meningkatkan tekanan osmotik medium (Winarno 1982 dalam Danitasari, 2010). Petis adalah suatu produk olahan hasil perikanan, yang dibuat dari hasil ekstrak ikan melalui proses perebusan dan selanjutnya dipekatkan atau dikentalkan dengan penambahan bahan pembantu dan bahan penyedap. Petis ikan yang terdapat di Indonesia merupakan hasil penyaringan dari proses perebusan (pemindangan) ikan, atau limbah hasil perebusan (pemindangan) dari ikan yang tidak dipergunakan lagi namun mengandung zat gizi yang cukup tinggi. Hasil penelitian Danitasari (2010), menyatakan bahwa air rebusan ikan dari industri pemindangan ikan tongkol dapat dimanfaatkan sebagai bahan baku petis ikan dan memiliki karakteristik rasa asin dan bau amis tetapi masih memiliki nilai gizi protein yang cukup tinggi. Hasil pengujian petis ikan tongkol disajikan pada Tabel 2.

Kandungan protein pada petis ikan sebesar $6,70 \%$. Nilai ini masih berada di bawah standar mutu menurut SNI 012346-2006 mengenai syarat mutu petis udang yang mencantumkan bahwa kandungan protein pada petis minimal 10\%. Hal ini dimungkinkan karena bahan baku petis ikan tongkol yang diperoleh adalah cairan rebusan ikan yang dipanaskan kembali, dimana kadar protein dipengaruhi oleh lama pemasakan. Pemberian gula dalam proses pembuatan petis dapat mempengaruhi kandungan protein, aktivitas air dan jumlah mikroba. Selama proses pengolahan bahan pangan termasuk petis dapat mengalami kerusakan protein karena adanya reaksi antara protein dengan gula pereduksi. Kandungan karbohidrat pada petis ikan juga akan meningkat melebihi jumlah protein akibat pemberian gula. Semakin banyak jumlah gula yang ditambahkan, kadar protein pada petis ikan semakin 
menurun. Penambahan gula juga dapat secara efektif digunakan sebagai pengawet karena sifatnya yang dapat menarik air dari bahan pangan yang diolah sehingga aktivitas mikroba dapat terhambat yang pada akhirnya dapat memperpanjang masa simpan makanan dengan aktivitas air yang lebih rendah.

Tabel 2.

Karakteristik Petis Ikan Tongkol

\begin{tabular}{lcc}
\hline \multicolumn{1}{c}{ Parameter } & Satuan & Petis Ikan \\
\hline Kadar air & $\%$ & 12,5 \\
Kadar abu & $\%$ & 7,69 \\
Kadar protein & $\%$ & 6,7 \\
Kadar lemak & $\%$ & 0,2 \\
Kadar karbohidrat & $\%$ & 72,9 \\
pH & & 5,32 \\
Aktivitas air & Aw & 0,62 \\
Mikrobiologi & CFU/ml & $1,2 \times 10^{6}$ \\
Cemaran logam: & & \\
- Hg & Ppb & Tidak Terdeteksi \\
- Pb & Ppb & Tidak Terdeteksi \\
- Fe & Ppm & 39,52 \\
Kadar garam & $\%$ & 9,44 \\
Kadar histamin & ppm & 11,88 \\
Viskositas & $\mathrm{cp}$ & 150000 \\
\hline Sumber: Danitasari, 2010.
\end{tabular}

Hal yang sama juga diungkapkan oleh Astawan dalam Isnaeni (2014), bahwa air rebusan ikan pindang juga dapat dimanfaatkan sebagai bahan baku pembuatan petis ikan. Kompoisi gizi pada petis sangat bervariasi tergantung dari bahan baku yang digunakan dan cara pembuatannya. Secara umum, petis ikan dengan bahan baku air rebusan ikan pindang mempunyai kandungan unsur gizi energi $151 \mathrm{kkal}$, air $56 \%$, protein $20 \%$, lemak $0,2 \%$, karbohidrat $24 \%$, kalsium $37 \mathrm{mg} / \mathrm{l}$, fosfor $36 \mathrm{mgl}$, besi 2,8 $\mathrm{mg} / \mathrm{l}$.

Pemanfaatan air limbah perikanan juga sudah dilakukan oleh industri dengan skala yang lebih besar seperti pada industri perikanan PT. Delta Pasific Indotuna di Kota Bitung, Manado. Limbah cair hasil olahan ikan dari industri tersebut diolah dengan teknologi fish juice menjadi sejenis kecap yang dikenal dengan nama petis ikan untuk dijual kembali. Bahkan dalam 3 bulan, industri tersebut mampu menghasilkan 10 ton petis ikan dari pemanfaatan air limbah olahan ikan (Noel, 2013).

\section{PAKAN TERNAK}

Limbah cair industri pemindangan ikan banyak mengandung bahan-bahan organik seperti sisa daging, isi perut ikan, protein, lemak dan karbohidrat yang dapat dengan cepat membusuk (Gonzales dalam Oktavia dkk, 2012). Bau tidak sedap merupakan bentuk pencemaran lingkungan akibat pembuangan limbah cair pemindangan ikan dimungkinkan karena pembusukan 
protein. Menurut Kementerian Lingkungan Hidup dalam Murniati (2007), limbah cair pengolahan pemindangan ikan mengandung nilai gizi yang cukup tinggi yang dapat dimanfaatkan untuk pangan dan pakan dengan cara membuat produk protein konsentrat.

Pemanfaatan limbah cair pemindangan ikan menjadi pakan ternak memerlukan limbah perikanan lain seperti kulit rajungan, udang sebagai bahan baku kitosan. Kitosan inilah yang akan digunakan sebagai koagulan dalam proses koagulasi protein dari limbah cair industri pemindangan ikan. Kitosan dapat digunakan untuk pengolahan limbah seperti industri pengolahan pangan dan untuk memisahkan protein dari limbah. Padatan yang diperoleh dapat dimanfaatkan sebagi sumber protein dalam makanan ternak (Bough dan Lande dalam Murniati, 2007). Komposisi beberapa kandungan nutrisi bahan baku pakan menurut Deptan (1996) disajikan pada Tabel 3.

Tabel 3.

Komposisi Beberapa Kandungan Nutrisi Bahan Baku Pakan

\begin{tabular}{cc} 
Kandungan Nutrisi & Ukuran (\% berat) \\
\hline Protein & $\min 35 \%$ \\
Lemak & maks $5 \%$ \\
Serat Kasar & maks $3 \%$ \\
Kadar Air & $10-12 \%$ \\
Kadar Abu & maks $20 \%$ \\
\hline
\end{tabular}

Sumber: Deptan, 1996.

Dengan mengetahui komposisi kandungan nutrisi bahan baku pakan pada Tabel 3 dan karakteristik limbah cair pemindangan ikan, diharapkan limbah cair pemindangan dapat memenuhi nutrisi sebagai bahan baku pakan.

\section{Penelitian Murniati}

(2007) menyebutkan bahwa setelah dilakukan proses koagulasi dengan $\mathrm{pH} 7$ dan jumlah kitosan $1000 \mathrm{mg} / \mathrm{l}$, kadar protein yang diperoleh sebesar 50,56\%; kadar lemak 4,25\%; kadar serat 2,95\%; kadar air $10,35 \%$ dan kadar abu 6,13\%. Kadar protein ini jauh meningkat dari kadar protein limbah cair pemindangan ikan sebelum dilakukan koagulasi yaitu sebesar 12,38\%. Peningkatan kadar protein ini disebabkan adanya penggumpalan protein dalam limbah cair pemindangan ikan dengan adanya penambahan kitosan sebagai koagulan yang dapat meningkatkan gugus $\mathrm{NH}_{3}{ }^{+}$ dalam larutan.

Kadar protein, kadar lemak, kadar serat, kadar air dan kadar abu pada limbah cair pemindangan ikan setelah dikoagulasi menggunakan $1000 \mathrm{mg} / \mathrm{l}$ kitosan dengan pH 7 sudah memenuhi standar kadar protein, kadar lemak, kadar serat, kadar air dan kadar abu untuk dapat digunakan sebagai bahan baku pakan ternak yang diijinkan pemerintah seperti pada Tabel 3 dimana kadar protein minimal 35\%, kadar lemak maksimal 5\%, kadar serat maksimal 3\%, kadar air 10-12\%, dan kadar abu maksimal $20 \%$. 


\section{PUPUK CAIR ORGANIK}

Penggunaan pupuk kimia di bidang pertanian secara terus-menerus, tanpa disadari akan merugikan petani. Hal ini dikarenakan pemakaian pupuk kimia dalam jangka panjang dapat merusak sifat fisik, kimia dan biologi tanah sehingga kemampuan tanah untuk mendukung ketersediaan air, hara dan kehidupan mikroorganisme menurun. Pemanfaaatan limbah cair perikanan bisa menjadi salah satu alternatif bahan baku pembuatan pupuk cair organik. Pada dasarnya, limbah cair perikanan tidak bisa langsung dimanfaatkan sebagai pupuk cair karena kandungan organiknya berupa lemak dan protein tidak dapat diserap langsung oleh tanaman. Kandungan organik tersebut perlu dipecah atau didegradasi menjadi senyawa-senyawa organik yang lebih sederhana sehingga dapat diserap oleh tanaman. Limbah cair industri perikanan mengandung banyak protein dan lemak, sehingga mengakibatkan nilai nitrat dan amonia yang cukup tinggi, menurut Ditjen Perikanan Budidaya dalam Waryanti dkk (2013), limbah ikan dapat dimanfaatkan sebagai bahan baku pupuk organik lengkap.
Dwicaksono dkk (2013) dalam penelitiannya melakukan penambahan aktivator (EM4) sebanyak $25 \mathrm{ml} / \mathrm{l} \mathrm{ke}$ dalam limbah cair perikanan. Dari hasil penelitian diketahui bahwa rata-rata pengujian yang dihasilkan dari variasi dengan penambahan $25 \mathrm{ml} / \mathrm{l}$ EM4 pada limbah cair industri perikanan mempunyai kandungan C-organik 4,5\%; kandungan $\mathrm{N}$-total $0,0037 \%$; kandungan P-total 4-6\% dan kandungan K-total $0,0032 \%$. Nilai ini masih belum memenuhi standar pupuk organik cair menurut Peraturan Menteri Pertanian No 70 tahun 2011 seperti yang tersaji pada Tabel 4.

Namun penelitian ini telah membuktikan bahwa penambahan konsentrasi EM4 sebanyak $25 \mathrm{ml} / \mathrm{l}$ pada limbah cair perikanan, mempunyai nilai rata-rata parameter yang lebih tinggi dari limbah cair perikanan yang tidak diberi tamahan EM4. Hal ini disebabkan adanya perbedaan komposisi bahan yang dicampurkan sehingga mempengaruhi kandungan nutrisi organik di dalamnya. Penambahan cairan EM4 berfungsi sebagai bioaktivator yang mampu merombak senyawa organik dan kandungan NPK di dalam limbah cair industri perikanan. 
Tabel 4.

Persyaratan Teknis Minimal Pupuk Cair Organik

\begin{tabular}{|c|c|c|}
\hline Parameter & Satuan & $\begin{array}{c}\text { Standar } \\
\text { Mutu }\end{array}$ \\
\hline C-organik & $\%$ & $\min 6$ \\
\hline Bahan ikutan (plastik, kaca, kerikil) & $\%$ & maks 2 \\
\hline \multicolumn{3}{|l|}{ Logam berat } \\
\hline - As & ppm & maks 2,5 \\
\hline$-\mathrm{Hg}$ & ppm & maks 0,25 \\
\hline$-\mathrm{Pb}$ & ppm & maks 12,5 \\
\hline$-\mathrm{Cd}$ & ppm & maks 0,5 \\
\hline $\mathrm{pH}$ & & $4-9$ \\
\hline \multicolumn{3}{|l|}{ Hara makro } \\
\hline$-N$ & $\%$ & $3-6$ \\
\hline$-\mathrm{P} 2 \mathrm{O} 5$ & $\%$ & $3-6$ \\
\hline$-\mathrm{K} 2 \mathrm{O}$ & $\%$ & $3-6$ \\
\hline \multicolumn{3}{|l|}{ Mikroba kontaminan } \\
\hline - E. Coli & $\mathrm{MPN} / \mathrm{ml}$ & maks 102 \\
\hline - Salmonella sp & $\mathrm{MPN} / \mathrm{ml}$ & maks 102 \\
\hline \multicolumn{3}{|l|}{ Hara mikro } \\
\hline - Fe total & ppm & $90-900$ \\
\hline - Fe tersedia & ppm & $5-50$ \\
\hline- Mn & ppm & $250-5000$ \\
\hline$-\mathrm{Cu}$ & ppm & $250-5000$ \\
\hline$-\mathrm{Zn}$ & ppm & $250-5000$ \\
\hline$-B$ & ppm & $125-2500$ \\
\hline$-\mathrm{Co}$ & ppm & $5-20$ \\
\hline - Mo & ppm & $2-10$ \\
\hline \multicolumn{3}{|l|}{ Unsur lain } \\
\hline$-\mathrm{La}$ & ppm & 0 \\
\hline$-\mathrm{Ce}$ & $\mathrm{ppm}$ & 0 \\
\hline
\end{tabular}

Sumber: Peraturan Menteri Pertanian No 70 tahun 2011.

\section{KESIMPULAN}

Meningkatnya industri pengolahan perikanan mengakibatkan peningkatan jumlah limbah yang dihasilkan dalam volume besar terutama limbah cair baik dari proses pencucian maupun dari proses produksinya. Pemanfaatan limbah cair perikanan menjadi berbagai produk- produk baru akan sangat membantu dalam peningkatan kesejahteraan masyarakat dan tentu saja akan meringankan beban lingkungan dalam mengatasi limbah cair perikanan yang selama ini berpotensi mencemari lingkungan karena langsung dibuang ke lingkungan. Limbah cair pemindangan ikan ini dapat dimanfaatkan menjadi 
bahan baku pembuatan peti ikan, pakan ternak dan pupuk cair organik.

\section{DAFTAR PUSTAKA}

Danitasari, S. M. 2010. Karakterisasi Petis Ikan dari Limbah Cair Hasil Perebusan Ikan Tongkol (Euthynnus affinis). Skripsi. Fakultas Perikanan dan Ilmu Kelautan. Bogor : Institut Pertanian Bogor.

Departemen Pertanian. 1996. Standar

Nasional Indonesia No. 01-27151996 tentang Pemanfaatan Limbah Pemindangan Ikan dan Pengalengan Ikan Untuk dijadikan Bahan Pakan Ternak. Jakarta.

Dinas Kelautan dan Perikanan Kabupaten Pati. 2013. Daftar Pengolah Ikan Se-Kabupaten Pati Tahun 2013. Pati.

Dwicaksono, M. R. B., B. Suharto., L. D.

Susanawati. 2013. Pengaruh

Penambahan Effective

Microorganisms pada Limbah Cair Industri Perikanan Terhadap Kualitas Pupuk Cair Organik. Jurnal Sumberdaya Alam \& Lingkungan.

Isnaeni, A. N., F. Swastawati., L. Rianingsih. 2014. Pengaruh Penambahan Tepung yang Berbeda Terhadap Kualitas Produk Petis Dari Cairan Sisa Pengukusan Bandeng (Chanos chanos Forsk) Presto. Jurnal Pengolahan dan Bioteknologi Hasil Perikanan, 3(3): 40-46.

Murniati, D. 2007. Pemanfaatan Kitosan Sebagai Koagulan Untuk Memperoleh Kembali Protein Yang Dihasilkan Dari Limbah Cair Industri Pemindangan Ikan. Tesis. Sekolah Pasca Sarjana.
Magister Teknik Kimia. Medan: Universitas Sumatera Utara.

Noel, F. 2013. Limbah PT. Indotuna Jadi Petis Ikan. Tribun Manado, 12 September http://manado.tribunnews.com/201 3/09/12/limbah-pt-indotuna-jadipetis-ikan, diakses tanggal 11 Nopember 2014).

Oktavia, D. A. dkk. 2012. Pengolahan Limbah Cair Perikanan Menggunakan Konsorsium Mikroba Indigenous Proteolitik dan Lipolitik. Agrointek, 6(2): 6571.

Peraturan Menteri Pertanian Nomor 70 Tahun/Permentan/SR. 140/10 Tahun 2011 tentang Pupuk Organik, Pupuk Hayati dan Pembenah Tanah.

Waryanti, A., Sudarno., E. Sutrisno. 2013. Studi Pengaruh Penambahan Sabut Kelapa pada Pembuatan Pupuk Cair dari Limbah Air Cucian Ikan terhadap Kualitas Unsur Hara Makro (CNPK).

Wijatmoko, A. 2004. Pemanfaatan Asam-asam Organik (Asam Cuka, Jeruk Nipis (Citrus auratifolia) dan Belimbing Wuluh (Avverhoa blimbi) Untuk Mengurangi Bau Amis Petis Ikan Ikan Layang (Decaptterus sp). Skripsi. Bogor: Institut Pertanian Bogor.

\section{BIODATA PENULIS}

Arieyanti Dwi Astuti, lahir 24 Agustus 1984 di kota Pati Jawa Tengah. Sarjana (S1) dari Universitas Diponegoro (UNDIP) Semarang Jurusan Teknik Lingkungan Tahun 2007. Saat ini bekerja sebagai peneliti di Kantor Penelitian dan Pengembangan Kabupaten Pati. 